\title{
Vulnerability of ten eucalyptus varieties to predation by cattle in a silvopastoral system
}

\author{
Maria Fernanda Guerreiro • Maria Luiza Franceschi Nicodemo • \\ Vanderley Porfírio-da-Silva
}

Received: 2 July 2014/Accepted: 16 February 2015/Published online: 22 February 2015

(C) Springer Science+Business Media Dordrecht 2015

\begin{abstract}
Silvopastoral systems have been increasingly adopted in Brazil, often supported by public policies, such as the federal government's "Low Carbon Agriculture" program. These systems integrate diversification, income generation and environmental protection. However, predation of mature trees by cattle can be a problem, causing large economic losses. As the causes of this predation are not precisely known, few alternatives are available to prevent or reduce damages. The present study aimed to evaluate the vulnerability of Eucalyptus grandis, E. saligna, E. pellita, E. dunni, E. urophylla, E. urograndis (clones I144, I224, C219 and H13) and the clone COP 1277, an $E$. grandis $\times E$. camaldulensis hybrid, to predation by cattle. Damages caused by chewing leaves and bark and breaking branches and trunks were evaluated in a silvopastoral system comprised of Brachiaria decumbens, cattle and Eucalyptus spp. The cattle showed a marked selection of E. grandis and E. urograndis I144 clone. The eucalyptus types least prone to damage were E. pellita and E. urograndis $\mathrm{H} 13$ clone.
\end{abstract}

M. F. Guerreiro

LF Desenvolvimento, Brotas, SP, Brazil

M. L. F. Nicodemo ( $\square)$

Embrapa Pecuária Sudeste, São Carlos, SP, Brazil

e-mail: marialuiza.nicodemo@embrapa.br

V. Porfírio-da-Silva

Embrapa Florestas, Colombo, PR, Brazil
Keywords Agroforestry systems · Herbivory · Wood

\section{Introduction}

Silvopasture is a sustainable production strategy that integrates stock raising and timber production in the same area. The presence of trees in pastures provides an extra source of income for the farmer, better environmental protection, improved animal welfare and increased soil fertility and pasture production. Eucalyptus spp. are among the prevalent tree species in silvopastoral systems in Brazil (Balbino et al. 2011). The trees should be protected from the cattle during their initial development, which is achieved by physical barriers such as fences around immature trees (Porfirio-da-Silva et al. 2009; Garret et al. 2004; Lehmkuhler et al. 2003) or by alley cropping systems, until they have size to endure the presence of cattle. In general, when the stem diameter overbark at breast height $(1.3 \mathrm{~m})$ reaches $6-8 \mathrm{~cm}$, it is possible to allow grazing without causing significant damage to trees. In the case of eucalyptus species, this takes about 12 months when the planting is properly managed and the genetic material is adequate for the region. However, even after the trees reach this size, damages to the bark can still be caused by cattle (Medrado et al. 2009; Porfirio-da-Silva et al. 2012). Despite the reports, the reason for eucalyptus bark stripping by 
cattle is largely unknown. Among the hypotheses suggested to explain this type of behavior are nutritional imbalances, such as mineral deficiency and low fiber concentration, and behavioral problems. Various factors can affect animal offense to the trees (Nolte 2003), among them the number and density of animals, availability of other food alternatives besides grass and trees and the palatability of the trees in relation to the alternative food source. Herd socialization is another factor that can influence animal offense to the tree. The observation of one animal consuming a determined food can induce other animals to do the same. If there is no adverse effect, all the animals will continue eating the same new food (Ralphs and Provenza 1999). When ingesting a plant or parts of one, the animal develops a reaction of ingestion or aversion, which allows herbivores to differentiate foods so as to optimize their ingestion of nutrients and toxins (Westoby 1974; Provenza et al. 2003).

In evaluating the damage caused by horses to different eucalyptus species, Ashton (2005) observed that the outer bark layer is the first indicator of palatability, and if the first bites do not cause any negative reaction, the animal will repeatedly chew the bark. The above mentioned effect may be verified on trees whose bark has been stripped, but the attack has not evolved to greater damage, unlike other trees where bark has been repeatedly stripped causing great damage. Nombekela et al. (1994), studying the dietary preferences of lactating cows, showed that the animals prefer sweetness (sucrose at $1.5 \%$ of dry matter), over sourness $(\mathrm{HCl} 1.25 \%)$, bitterness (urea $1 \%$ ) or saltiness $(\mathrm{NaCl} 4 \%)$. The dry matter ingestion of the sweet diet was on average $12.8 \%$ greater than the control diet. Salts such as sodium chloride are also generally very palatable to herbivores, perhaps because sodium ions have important biological functions and are often not plentifully available in plants (Beauchamp 1995). There are relatively few studies investigating the palatability of sour diets (high in acid) to livestock, but it is assumed that such foods are generally avoided, perhaps because of the damages acids can cause to the oral cavity. In other words, the aversion is not necessarily due to the sour taste, but instead to the irritation that acids above a certain concentration can cause (Beauchamp 1995). Finally, a bitter flavor plays an important role in deterring animals from eating harmful and toxic substances, especially alkaloids (Beauchamp 1995). Go (2006) identified 29 bitter taste receptor genes in cattle, indicating the potential use of the taste sense for recognition and adaptation to the environment. The presence of certain compounds in the plant parts accessible to cattle can thus induce or discourage consumption.

The palatability of a plant can change, including in function of silvicultural practices, such as fertilization and pruning. Variations in conditions of light, nutrients and atmospheric conditions can alter the chemical composition of plants and their susceptibility to consumption by herbivores. The genus Eucalyptus includes over 700 species. The foliage of these trees is consumed by many insects and herbivorous mammals. The genetic basis for the variation in resistance to herbivore feeding of some eucalyptus varieties has been correlated with differences in the concentration of chemical defense compounds (such as compounds of 2,4,6 trihydroxybenzoic acid $=\mathrm{CFP}$ ), condensed tannins and essential oils (O'Reilly-Wapstra et al. 2005). Herbivores are selective in choosing the arboreal species they eat. In this study, we assessed the susceptibility of 10 eucalyptus species or clones to damage from cattle in a silvopastoral system.

\section{Materials and methods}

The study was carried out in the municipality of Brotas, São Paulo state, Brazil, on the Nelson Guerreiro Farm (coordinates $22^{\circ} 11^{\prime} 02.4000^{\prime \prime} \mathrm{S}, 48^{\circ} 15^{\prime} 35.5212^{\prime \prime} \mathrm{W}$ ). The farm is located in a foothill region, with declivity of $6 \%$, in the transition Atlantic Forest-Cerrado biome, at an altitude of $562 \mathrm{~m}$. The climate is humid subtropical, with cool and dry winters and hot and rainy summers (CWa on the Köppen scale), with minimum average annual temperature of $18{ }^{\circ} \mathrm{C}$, maximum of $23^{\circ} \mathrm{C}$ and overall average of $21.6^{\circ} \mathrm{C}$. The average yearly rainfall is between 1300 and $1400 \mathrm{~mm}$. The soil is characterized as a yellow-red latosoil with $10 \%$ clay.

The trees were planted in strips running crosswise in relation to the slope, in an area of 5.93 ha. Ten species or clones were planted in May 2012: Eucalyptus grandis, E. saligna, E. pellita, E. dunni, E. urophylla, E. urograndis (clones I144, I224, C219 and H13) and the clone COP 1277, a hybrid of E. grandis $\times$ E. camaldulensis. The fertilization consisted of $110 \mathrm{~g} / \mathrm{plant}$ of $6-30-6+0.5 \% \mathrm{Zn}+1.0 \% \mathrm{~B}$ at the 
time of planting; $300 \mathrm{~g} /$ plant of 10-10-10 $+0.5 \% \mathrm{~B}$ as side dressing, applied 9 months after planting; and $120 \mathrm{~g} /$ plant of 15-00-15 + 1\% B, applied 19 months after planting. The seedlings were planted in strips of three rows each, with spacing of $3 \mathrm{~m} \times 2 \mathrm{~m}$, while the spacing between strips was $12-40 \mathrm{~m}$, with density of 308 plants/ha. The trees were planted in two blocks, with 81 seedlings of each variety per block. Eighteen trees of each eucalyptus variety were evaluated from each block (Fig. 1).

Later the whole area was subdivided in 10 paddocks for grazing management. The area between the strips of trees was occupied with Brachiaria decumbens and was divided into 10 paddocks covering from 0.42 to 0.51 ha, plus a rest area of 0.27 ha. The grazing was rotational, in which the animals remained in the area intermittently, in the period between 8 October 2013 and 8 March 2014, a total of 85 days, divided into four grazing cycles. In the first cycle, each paddock was occupied for 3 days, while in the second the occupation was 1 day, in the third it was 3 days and in the fourth it was 2 days. These occupation periods were determined by evaluating the height of the remaining grass after grazing, which in the case of Brachiaria species should be between 15 and $20 \mathrm{~cm}$ (Pereira 2005). Grass samples were obtained by simulated grazing and were analyzed for crude protein concentration, neutral detergent fiber (NDF), acid detergent fiber and in vitro digestibility of dry matter (\% dry matter). The respective values found were $11.06 \pm$ $1.52,52.86 \pm 1.56,28.41 \pm 1.54$ and $68.77 \pm 1.71$.

The herd was composed of 40 Nelore heifers between 13 and 14 months old, with average live

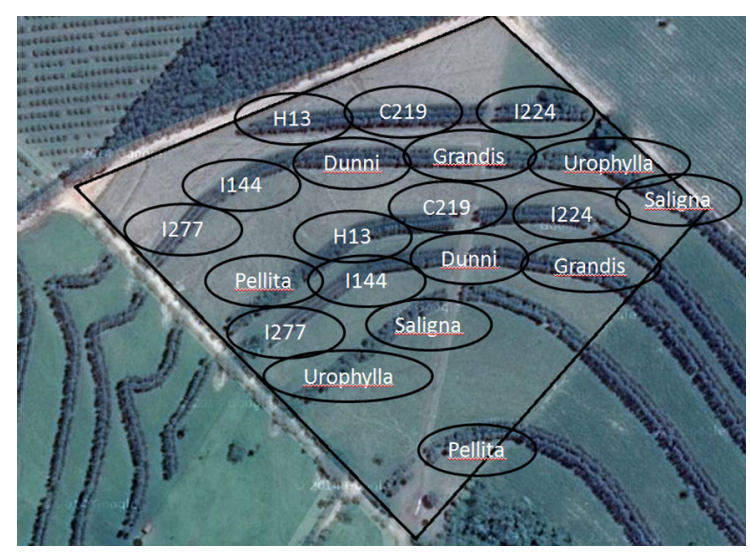

Fig. 1 Distribution of eucalyptus in the experimental area weight of $239.4 \mathrm{~kg} ; 2$ Girolanda heifers with age of 13 months and average weight of $247 \mathrm{~kg}$; and 9 Gir dairy cows with age of 5 years and weight of $484 \mathrm{~kg}$, equivalent to $32 \mathrm{AU}$ ( $\mathrm{AU}=$ animal unit). The damages caused to the trees by the animals were evaluated from 17 February to 7 March 2014. In our conditions it is a common practice to allow beef and dairy cattle to silvopastures when the well-managed trees are about 12 month-old, with diameter at breast height (dbh) $>6 \mathrm{~cm}$. The average $\mathrm{dbh}(\mathrm{cm})$ and height $(\mathrm{m})$ of these trees in July 2013, at 13 months of age, were respectively: 6.60 and 8.01 (E. grandis), 6.16 and 7.00 (E. saligna), 6.09 and 6.48 (E. pellita), 6.94 and 8.71 (E. dunni), 6.28 and 7.31 (E. urophylla), E. urograndis: 7.43 and 10.10 (clone I144), 7.18 and 9.03 (clone I224), 7.35 and 11.31 (clone C219), 6.35 and 8.26 (clone H13), and 7.10 and 8.77 (clone COP 1277, a hybrid of E. grandis $\times$ E. camaldulensis). The average $\mathrm{dbh}(\mathrm{cm})$ and height $(\mathrm{m})$ of the trees in April 2014, at 23 months of age, were respectively: 11.01 and 11.25 (E. grandis), 8.33 and 8.13 (E. saligna), 8.71 and 8.84 (E. pellita), 11.07 and 11.19 (E. dunni), 10.05 and 9.96 (E. urophylla), E. urograndis: 11.27 and 12.59 (clone I144), 11.21 and 11.17 (clone I224), 11.39 and 11.47 (clone C219), 10.14 and 11.11 (clone H13), and 10.72 and 11.16 (clone COP 1277, a hybrid of $E$. grandis $\times E$. camaldulensis).

The cattle had access to the paddocks with $B$. decumbens and eucalyptus trees, with the factors other than grazing period (climate, soil, management, diet) held constant. For assessment of the damage, we used the method described by Porfirio-da-Silva et al. (2012). The damages caused by the animals were classified according to the parts of the plant affected: $\mathrm{Tb}=$ trunk breakage, $\mathrm{Ti}=$ trunk injury reaching the wood by removal of cambium tissue, $\mathrm{Bb}=$ branch breakage, $\mathrm{Bi}=$ bark injury, without reaching the cambium, $\mathrm{Sb}=$ stem breakage and browsing on leaves, and $\mathrm{Li}=$ large injury (greater than $5 \mathrm{~cm}$ in diameter). A system of weighting and scoring was established for the different types of damage: $\mathrm{Tb}=10.0, \mathrm{Ti}=4.0, \mathrm{Bb}=2.0, \mathrm{Bi}=1.5, \mathrm{Sb}=1.0$, and $\mathrm{Li}=1.0$. Trunk breakage $(\mathrm{Tb})$ may lead to tree loss, which justify the greatest weight, 10; lesions to the leaves and branches ( $\mathrm{Sb}$ or $\mathrm{Bb}$ ), on the other hand, may be fully recovered, which guaranteed them a lower weight value of 1.0 or 2.0. For example, a tree showing: $\mathrm{Sb}(=1.0)+\mathrm{Bb}(=2.0)+\mathrm{Bi}(=1.5)$ would report a final score of 4.5 points. The criterion adopted 
related the type of damage and its importance for the tree's future development. The final score is the sum of the various damages suffered. The occurrence of $\mathrm{Li}$ (stem injury larger than $5 \mathrm{~cm}$ in diameter), Ti (trunk injury reaching the wood by removal of cambium tissue) and $\mathrm{Bb}$ (branch breakage) are always associated with other damages. Then, based on the type of damage and its importance for future development, five damage intensity classes were established: $\mathrm{d} 0=$ nil $(\mathrm{d} 0=0), \mathrm{d} 1=$ low $(0<\mathrm{d} 1 \leq 3), \mathrm{d} 2=$ medium $(3<\mathrm{d} 2 \leq 6), \mathrm{d} 3=$ high $(6<\mathrm{d} 3<10)$, and $\mathrm{d} 4=$ extreme $(\mathrm{d} 4=10)$.

The homogeneity of the variance of the sum of the damages was analyzed by the Levene tests, using the $\mathrm{R}$ program (R Development Core Team 2008). Since the variables were not distributed normally for application of parametric tests, the differences were analyzed by the Kruskal-Wallis test, followed by a multiple comparison test, using the Infostat statistical package (Di Rienzo et al. 2011), with significance of 0.05 .

\section{Results and discussion}

There were significant differences in the attack on several of the eucalyptus varieties (Table 1). The one most affected was $E$. grandis, followed by $E$. urograndis clone I144, while E. dunni, E. urograndis

Table 1 Mean and standard deviation of the damages caused to eucalyptus types

\begin{tabular}{llll}
\hline Eucalyptus & $\mathrm{n}$ & Mean & $\mathrm{SD}$ \\
\hline H13 & 36 & $1.14 \mathrm{~A}$ & 0.52 \\
PELLITA & 36 & $1.44 \mathrm{AB}$ & 0.88 \\
C219 & 36 & $1.64 \mathrm{BC}$ & 0.88 \\
DUNNI & 36 & $1.97 \mathrm{BCD}$ & 1.47 \\
UROPHYLLA & 36 & $2.07 \mathrm{CD}$ & 1.38 \\
SALIGNA & 36 & $2.14 \mathrm{CD}$ & 1.29 \\
I224 & 36 & $2.31 \mathrm{CDE}$ & 1.49 \\
COP 1277 & 36 & $2.40 \mathrm{DE}$ & 1.13 \\
I144 & 36 & $2.78 \mathrm{E}$ & 1.22 \\
GRANDIS & 36 & $4.35 \mathrm{~F}$ & 1.81 \\
\hline
\end{tabular}

E. grandis (GRANDIS), E. saligna (SALIGNA), E. pellita (PELLITA), E. dunni (DUNNI), E. urophylla (UROPHYLLA), E. urograndis (clones I144, I224, C219 and H13) and the clone COP 1277 , a hybrid of E. grandis $\times$ E. camaldulensis

Different means indicate a significant difference by the Kruskal-Wallis test $(\mathrm{P}<0.05)$ clone C219, E. pellita and E. urograndis clone H13 were less severely affected.

The susceptibility of E. grandis to cattle offense was previously reported by Medrado et al. (2009), who indicated generalized damages to E. grandis in a silvopastoral system with Brachiaria brizantha cv. Xaraés in the Paraná state, Brazil. The problem was noted when the trees were 3 years old. A partial estimate of the damages indicated the existence of injuries to $61 \%$ of the trees. The next year, this figure had risen to $92 \%$. Damages to the trunks reached the cambium and wood (xylem) in $30 \%$ of the trees. The damages observed in the present study involved the leaves (browsing), branches and bark. We did not observe any trunk breakage, probably because the trees were large enough to withstand the impact of the animals. Porfirio-da-Silva et al. (2012) only reported breakage by cattle of trees with stem diameter overbark at breast height $(1.3 \mathrm{~m})$ smaller than $6 \mathrm{~cm}$. We observed browsing damage to all the trees (Fig. 2), varying from $67 \%$ for E. dunni to $100 \%$ in the cases of E. grandis, E. pellita, I144 and COP 1277. The trees that suffered the greatest damages (Table 1) were also those whose leaves had been consumed in all the individuals, except for E. pellita, in which case although all the trees suffered from browsing, few of them showed injuries to the bark or trunks ( $\mathrm{Ti}, \mathrm{Bi}$ and Li).

According to Porfirio-da-Silva et al. (2012), browsing should be expected in silvopastoral systems, especially when the animals can reach the branches, suggesting pruning to reduce this occurrence as well as branch breakage $(\mathrm{Bb})$. Although browsing of a few leaves does not have a negative impact on the development of trees, branch breakage can cause injuries that allow the entry of pathogenic organisms. This breakage was not a common occurrence, only being observed in two trees, one E. saligna and the other E. urophylla.

Bark performs a wide range of functions in trees. The innermost bark layer is involved in the transport and storage of photoassimilates, while the outermost layer protects the plant against the entry of pathogens and protects the adjacent tissues from mechanical injuries (Romero 2006). The intensity of the damage (Fig. 3) depends on the depth and extension of the bark injury. When the lesion is restricted to the surface, without reaching the cambium and wood, the damaged part recovers uniformly. In the case of deeper damage, 


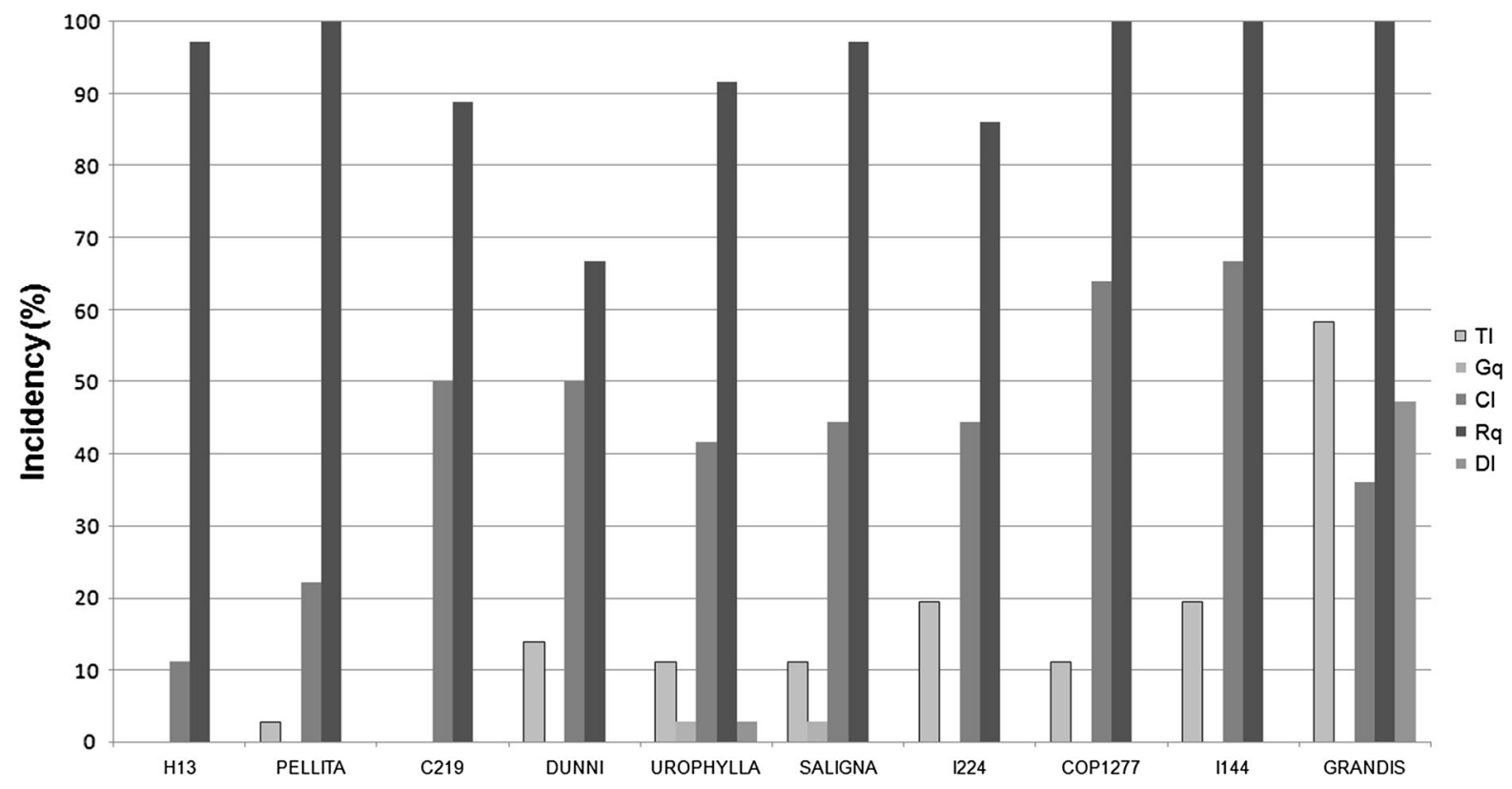

Fig. 2 Types of damage caused by cattle to each eucalyptus type: $S b$ stem damage and leaf loss by browsing, $B i$ bark injury, without reaching the cambium, $L i$ injury with diameter greater

than $5 \mathrm{~cm}, B b$ branch breakage, $T i$ trunk injury, reaching the wood. There were no broken trunks $(\mathrm{Tb})$

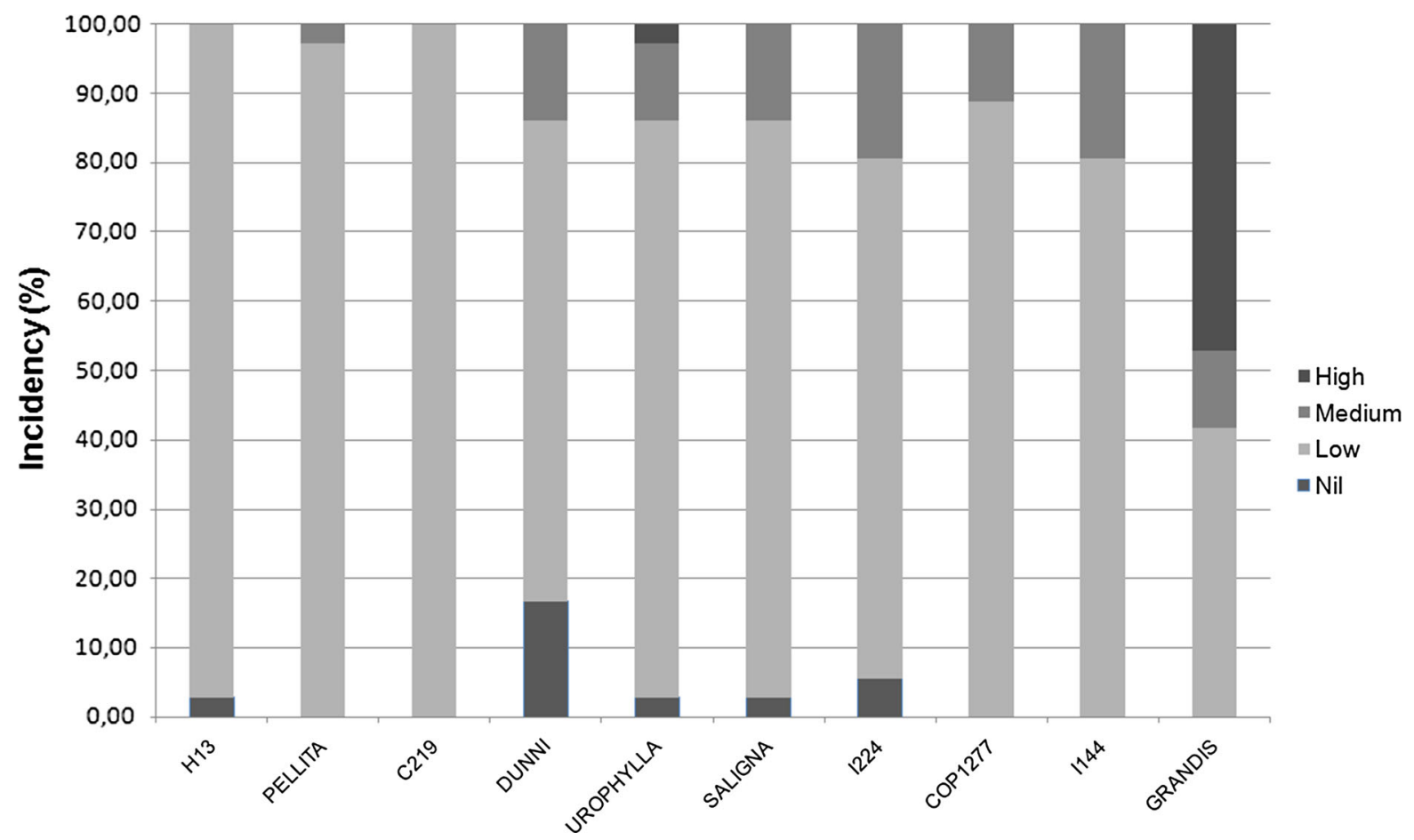

Fig. 3 Incidence and intensity of damages caused by cattle in each eucalyptus type [E. grandis (GRANDIS), E. saligna (SALIGNA), E. pellita (PELLITA), E. dunni (DUNNI), E. urophylla (UROPHYLLA), E. urograndis (clones I144,
I224, C219 and H13) and clone COP 1277, a hybrid of $E$. grandis $\times$ E. camaldulensis $]: \mathrm{d} 0=$ none $(\mathrm{d} 0=0), \mathrm{d} 1=$ low $(0<\mathrm{d} 1 \leq 3), \mathrm{d} 2=$ medium $(3<\mathrm{d} 2 \leq 6)$, and $\mathrm{d} 3=$ high $(6<\mathrm{d} 3<10)$ 
the healing is often only partial, facilitating infection by diseases and attack by pests, even to the point of causing death (Medrado et al. 2009). When deep injuries to the bark occur, a carbohydrate, callose, derived from the parenchymatic tissues, is deposited to seal the wound (Romero 2006). This can increase the attraction of cattle to the tree (Porfirio-da-Silva et al. 2012). Another negative aspect of deep bark injuries is the possibility of sprouting from epicormic buds below the damaged region, reducing the value of the wood (Porfirio-da-Silva et al. 2012). All the trees presented slight damage to the bark, varying from $11 \%(\mathrm{H} 13)$ to $64 \%$ (COP 1277).

No severe damages were suffered by trees of the C219 and H13 varieties, and only one individual of E. pellita (3\%) presented serious damages. E. grandis was the most susceptible, with $58 \%$ of the trees having serious injuries. The severe damage rates for the other varieties ranged from 10 to $20 \%$. Bark breakage and leaf browsing had little influence in differentiating the varieties, since no broken trunks were observed in any of the trees, and among the types evaluated, four were clones of the Urograndis hybrid (I144, I224, C219 and H13). However, the susceptibility of these clones to attack was singularly distinct: H13 and C219 were among the least affected varieties, while I144 was particularly susceptible.

Cattle offenses to trees do not have a clear cause. It has been associated with nutritional imbalances, such as deficiencies of minerals and fiber in the diet; monotony of the diet and animal stress; and insufficient forage (Medrado et al. 2009; Porfirio-da-Silva et al. 2012). Although we did not make a direct assessment of the availability of grass, the indications obtained from the residue height $(20 \mathrm{~cm})$, the quality of the grass and the weight gain recorded during the period $(0.274 \mathrm{~kg} / \mathrm{head} /$ day $)$ lead to the inference that the forage supply was adequate. The evaluation of the mineral supplement offered indicated sufficient supply of minerals. The consumption of materials not normally eaten is called depraved appetite or pica. It is observed when diets are deficient in phosphorous, sodium, potassium, iodine and cobalt. The consumption of $100 \mathrm{~g}$ of mineral-protein supplement per head/day, as observed in the present study, would allow adequate intake of the commonly deficient minerals, while potassium is generally adequate in forage grasses. The average percentages of crude protein found in $B$. decumbens are above $7 \%$, which is the minimum required for ruminants to enable fermentation and microbial synthesis of protein to occur as well as to provide ammonia and energy for ruminal microorganisms (Minson 1990). The fiber content of the grass was within the levels considered adequate: concentrations higher than 55-60\% of NDF are considered undesirable according to Van Soest (1994), indicating low quality of forage plants. The $B$. decumbens in this study had $53 \%$ NDF. Grasses with values of fiber insoluble in detergent acid of $30 \%$ or less have high consumption, while those with levels above $40 \%$ have low consumption (Noller et al. 1996). A low acid detergent fiber value is related to higher energy value, and it is desirable for this measure not to exceed $35 \%$ in forage (Mesquita et al. 2002). We believe the B. decumbens in this study was able to supply sufficient fiber to the cattle, even though the values observed were lower than those found by other authors. In any event, the attack on the trees was observed in the period of active growth of the pastures, when there was a greater participation of green leaves and lower fiber content. The in vitro digestibility was $68.77 \%$, higher than the $65 \%$ considered adequate for ruminant nutrition (Mesquita et al. 2002).

This study showed cattle marked selection of the bark of E. grandis and of the clones E. urograndis I144 and I224 for consumption. This problem can cause significant losses to farmers working with silvopastoral systems. In the case of E. grandis, $58 \%$ of the injuries caused to the bark reached the xylem. Previous report of bark stripping in E. grandis (Medrado et al. 2009) indicates that the inclusion of this species in silvopastoral systems should be considered carefully. Our evaluation showed other eucalypts less prone to damage, that could be used to generate similar products. Additional studies to characterize the composition and physical characteristics of the bark of these trees can shed more light on the attributes of eucalyptus species, to enable prevention of severe damage from cattle. Considering the role of management and tree nutrition on attractiveness of the plants to herbivores (O'Reilly-Wapstra et al. 2005), it is possible that silvicultural strategies could be pointed out to decrease tree attraction. Environmental enrichment, including the diversification of the forage available in the paddocks, could also be tested to decrease damage. 


\section{Conclusion}

The clones H13 and C219 of the hybrid E. urograndis are the least vulnerable to damage by cattle, while $E$. grandis and clone I144 of the hybrid E. urograndis are the most vulnerable among the varieties tested here. The vulnerability of tree species to cattle damage should be taken into account on the selection of trees for silvopastoral systems.

\section{References}

Ashton A (2005) Bark chewing by the wild horses of Guy Fawkes River National Park, NSW: impacts and causes. The University of New England, Armidale

Balbino LC, Cordeiro LAM, Porfirio-Da-Silva V, De Moraes A, Martinez GB, Alvarenga RC, Kichel AN, Fontaneli RS, Dos Santos HP, Franchini JC, Galerani PR (2011) Evolução tecnológica e arranjos produtivos de sistemas de integração lavoura-pecuária-floresta no Brasil. Pesqui Agropecu Bras 46:i-xii

Beauchamp GK (1995) Chemical signals and repellency: problems and prognosis. http://digitalcommons.unl.edu/cgi/ viewcontent.cgi ?article $=1004 \&$ context $=$ nwrcrepellants. Accessed 2 July 2014

Di Rienzo JA, Casanoves F, Balzarini M, Gonzalez L, Tablada CW InfoStat versión 2011. Grupo InfoStat, FCA, Universidad Nacional de Córdoba. http://www.infostat.com.ar. Accessed 4 April 2014

Garret HE, Kerley MS, Ladyman KP, Walter WD, Godsey LD, Van Sambeek JW, Brauer DK (2004) Hardwood silvopasture management in North America. Agrofor Syst 61:21-33

Go Y (2006) Lineage-specific expansions and contractions of the bitter taste receptor gene repertoire in vertebrates. Mol Biol Evol Soc 23:964-972

Lehmkuhler J, Felton EED, Schmidt DA, Bader KJ, Moore A, Huck MB, Garrett HE, Kerley MS (2003) Cattle performance and tree damage using various tree protection methods during tree establishment. Agrofor Syst 59:35-42

Medrado MJS, Porfírio-da-Silva V, Dereti RM, da Fonseca LR, Maier TF, Pinton ALM (2009) Danos provocados em eucalipto por bovinos criados em sistema silvipastoril no município de Cruzmaltina, PR. www.cnpf.embrapa.br/ publica/comuntec/edicoes/CT243.pdf. Accessed 2 July 2014

Mesquita EE, Fonseca DM, Nascimento Júnior D, Pereira OG, Pinto JC (2002) Efeitos de métodos de estabelecimento de braquiária e estilosantes e de doses de calcário, fósforo e gesso sobre alguns componentes nutricionais da forragem. Rev Bras Zootec 31:2186-2196

Minson DJ (1990) Forage in ruminant nutrition. Academic, New York

Noller CH, Nascimento Jr D, Queiroz DS (1996) Exigências nutricionais de animais em pastejo. In: SIMPÓSIO SOBRE MANEJO DE PASTAGEM, 13., 1996, Piracicaba, Brasil. Anais... Fundação de Estudos Agrários Luiz de Queiroz, Piracicaba 1997, pp 319-352

Nolte DL (2003) Repellents are socially acceptable tools. West For 48:22-23. http://digitalcommons.unl.edu/cgi/viewcontent. cgi? article $=1256 \&$ context $=i$ cwdm_usdanwrc. Accessed 2 July 2014

Nombekela SW, Murphy MR, Gonyou HW, Marden JI (1994) Dietary preferences in early lactation cows as affected by primary tastes and some feed flavors. J Dairy Sci 77: 2393-2399

O'Reilly-Wapstra JM, Potts BM, McArthur C, Davies NW (2005) Effects of nutrient variability on the genetic-based resistance of Eucalyptus globulus to a mammalian herbivore and on plant defensive chemistry. Oecologia 142: $597-605$

Pereira JM (2005) Manejo estratégico da pastagem. http://www. ceplac.gov.br/radar/semfaz/pastagem.htm. Accessed 20 March 2011

Porfirio-da-Silva V, Medrado MJS, Nicodemo MLF, Dereti RM (2009) Arborização de pastagens com espécies florestais madeireiras: implantação e manejo. www.cnpf.embrapa. br/publica/titulos/Cartilha_Arborizacao.pdf. Accessed 2 July 2014

Porfirio-da-Silva V, de Moraes A, Moletta JL, da Pontes LS, de Oliveira EB, Pelissari A, de Carvalho PCF (2012) Danos causados por bovinos em diferentes espécies arbóreas recomendadas para sistemas silvipastoris. Pesqui Florest Bras 32:67-76

Provenza FD, Villalba JJ, Dziba LE, Atwood SB, Banner RE (2003) Linking herbivore experience, varied diets, and plant biochemical diversity. Small Rumin Res 49:257-274

Ralphs MH, Provenza FD (1999) Conditioned food aversions: principles and practices, with special reference to social facilitation. Proc Nutr Soc 56:813-820

Romero C (2006) Trees responses to stem damage. Dissertation, University of Florida

R Development Core Team (2008) R: a language and environment for statistical computing. R Foundation for Statistical Computing. http://www.R-project.org. Accessed 2 July 2014

Van Soest PJ (1994) Nutritional ecology of the ruminant, 2nd edn. Cornell University Press, Ithaca

Westoby M (1974) An analysis of diet selection by large generalist herbivores. Am Nat 108:290-304 